\title{
Comparative assessment of three yeast samples for wine production from pineapple
}

\author{
Chukwuma Chrisaugunus Ekechukwua , Chukwunonso Christian Ikele ${ }^{\mathrm{a}}$, Chukwuemeka \\ Augustine Okafora, Ikenna Chukwudi Igwebuike ${ }^{a}$
}

${ }^{a}$ Department of Applied Microbiology and Brewing, Nnamdi Azikiwe University, Awka.

ABSTRACT Pineapple is an abundant fruit in Nigeria, which usually suffers post-harvest spoilage due to lack of preservation techniques. Its rich sugar content makes it a suitable substrate for wine production, which becomes a useful alternative to curbing its post-harvest spoilage. This research compared the production of wine from pineapple using Saccharomyces cerevisiae, Saccharomyces bayanus, and Saccharomyces ellipsoides. Yeast viability was assessed on YPG medium. To each fermenting jar was poured sterilized $3000 \mathrm{ml}$ must, comprising of a mixture of juice and $6 \mathrm{ml}$ of each yeast inoculum. Sodium metabisulphite $(0.4 \mathrm{~g} / \mathrm{l})$ was also aseptically added to each of the fermenting jars as a preservative and the fermenting jars were sealed with corks. Fermentation was allowed for twenty-eight (28) days within which different physical analyses were carried out $(\mathrm{pH}$, temperature, titratable acidity, specific gravity, reducing sugar, alcoholic content) for each day. Sensory evaluation of the finished products was conducted and the overall level of acceptance was determined. The viable counts of Saccharomyces cerevisiae, Saccharomyces bayanus, and Saccharomyces ellipsoides after growth on YPG medium were $3.3 \times 10^{6}, 3.5 \times 10^{6}$, and $3.8 \times 10^{6} \mathrm{cfu} / \mathrm{ml}$ respectively. There was decreased $\mathrm{pH}$, reducing sugar, and a specific gravity of the wine samples while, there was an increase in titratable acidity, alcohol content, and temperature. Significant differences $(p<0.05)$ existed in the overall acceptability of the wine samples with $S$. bayanus fermented wine having the least acceptance by taste panelists. Pineapple makes a good compatible raw material for wine production using varying yeast samples.

KEYWORDS: fermentation; saccharomyces; vinification.

Accepted December 2, 2020 Published online January 28, 2021

Cite this article: Ekechukwu et al. (2021) Comparative assessment of three yeast samples for wine production from pineapple. Multidisciplinary Science Journal 3 : e2021003, doi: 10.29327/multiscience.2021003.

\section{Avaliação comparativa de três amostras de levedura para produção de vinho de abacaxi}

RESUMO O abacaxi é uma fruta abundante na Nigéria, que geralmente sofre deterioração pós-colheita por falta de técnicas de preservação. Seu rico teor de açúcar o torna um substrato adequado para a produção de vinho, o que se torna uma alternativa útil para conter sua deterioração pós-colheita. Esta pesquisa comparou a produção de vinho de abacaxi usando Saccharomyces cerevisiae, Saccharomyces bayanus e Saccharomyces elipsoides. A viabilidade da levedura foi avaliada em meio YPG. Em cada pote de fermentação foi depositado $3000 \mathrm{ml}$ de mosto esterilizado, composto por uma mistura de sumo e $6 \mathrm{ml}$ de cada inóculo de levedura. Metabissulfito de sódio $(0,4 \mathrm{~g} / \mathrm{l})$ também foi adicionado assepticamente a cada um dos jarros de fermentação como conservante e os jarros de fermentação foram selados com rolhas. A fermentação foi permitida por vinte e oito (28) dias, nos quais foram realizadas diferentes análises físicas ( $\mathrm{pH}$, temperatura, acidez titulável, peso específico, açúcar redutor, teor alcoólico) para cada dia. A avaliação sensorial dos produtos acabados foi conduzida e o nível geral de aceitação foi determinado. As contagens viáveis de Saccharomyces cerevisiae, Saccharomyces bayanus e Saccharomyces elipsoides após crescimento em meio YPG, foram de $3,3 \times 10^{6}, 3,5 \times 10^{6}$ e 3,8 $\times 10^{6} \mathrm{cfu} / \mathrm{ml}$, respectivamente. Houve diminuição do $\mathrm{pH}$, redução do açúcar e do peso específico das amostras de vinho, enquanto, aumento da acidez titulável, do teor de álcool e da temperatura. Houveram diferenças significativas $(\mathrm{p}<0,05)$ na aceitabilidade geral das amostras de vinho com vinho fermentado de $S$. bayanus, tendo a menor aceitação pelos provadores. O abacaxi é uma boa matéria-prima compatível para a produção de vinho usando várias amostras de levedura.

PALAVRAS-CHAVE: fermentação; saccharomyces; vinificação. 


\section{Introduction}

Wine production is traditionally performed using red grapes and apples as fruit sources both locally and internationally. Red grapes and apples are not successfully grown in Nigeria in reasonable commercial quantities; thus, local wine production will invariably largely depend on the importation of these fruits for the production of standard wine that will draw reasonable market acceptability (Archibong et al 2015). However, Nigeria has some fruits whose must serve as substrates for wine production, but are not being used. These local fruits are grown in commercial quantities in the country and most times are not properly preserved post-harvest; thus, a good number of the fruits are lost to post-harvest spoilage.

Therefore, there is a need to channel these fruits away from spoilage to other value chain processes such as wine production. Some researchers (Idise 2012; Archibong et al 2015; Dellacasa et al 2016; Qi et al 2017; Chaudhary et al 2019) have pointed out the potential of harnessing pineapple as an indigenous Nigerian fruit for wine production due to its richness in sugars that can support yeast proliferation and consequent fermentation. A successful standard wine production using indigenous fruits will turn out to be a source of foreign exchange, grow the local currency, and contribute immensely to the gross domestic product (GDP) margin of the country. The quality of wine produced greatly depends on the yeast strains (Idise 2012). Published research articles (Archibong et al 2015; Qi et al 2017; Chaudhary et al 2019) on the use of pineapple for wine production have employed Saccharomyces cerevisiae for wine production. However, this research seeks to analyze a comparative wine production using other different yeast samples (Saccharomyces bayanus and Saccharomyces ellipsoides) to find out if industrialists stand a chance of producing quality wine with pineapple using some known brewing-grade yeasts aside from widely known Saccharomyces cerevisiae; as this will help in the expansion of winery as an industry in Nigeria.

\section{Material and Methods}

\section{Sample collection}

Pure culture of wine yeasts (Saccharomyces cerevisiae, Saccharomyces bayanus and Saccharomyces ellipsoides) were sourced from an indigenous wine production company in Imo State, Nigeria. Pineapple fruits were purchased from Eke-Awka Market, Anambra State, Nigeria.

\section{Viability test of the yeast samples}

The viability test of the yeast samples was determined with the viable count method according to Mirek and Tecza (2014). A one $\mathrm{ml}$ aliquot of the slurry containing each yeast samples was transferred into a test tube containing 5 $\mathrm{ml}$ phosphate buffer solution to form a stock solution, then $1 \mathrm{ml}$ from each tube was serially diluted using a tenfold serial dilution, inoculated onto YPG medium, and incubated at $28^{\circ} \mathrm{C}$ for 2 days after which colonies were counted.

\section{Preparation of the must}

Pineapple fruits (Ananas comosus) were washed, peeled, and sliced. The sliced fruits were then poured into a sterile juice extractor (in bits), connected to a power source, and switched on to blend and extract the juice. A $1000 \mathrm{ml}$ aliquot of the fruit juice was collected in turns into a sterile $1000 \mathrm{ml}$ fermenting flask, properly labeled, and was then pasteurized at $60^{\circ} \mathrm{C}$ for twenty minutes in a water bath (Jana 2011).

\section{Fermentation}

Twenty-one (21) different fermenting jars (3800 ml capacity) were clearly labeled with the name of the fruit and the corresponding yeast samples. To each fermenting jar was poured sterilized $3000 \mathrm{ml}$ must comprising of a mixture of juice and $6 \mathrm{ml}$ of each yeast inoculum. Sodium metabisulphite $(0.4 \mathrm{~g} / \mathrm{l})$ which serves as a preservative was also aseptically added to each of the fermenting jars and the fermenting jars were sealed with corks. Fermentation was allowed for twenty-eight (28) days within which different physical analyses were carried out $(\mathrm{pH}$, temperature, titratable acidity, specific gravity, reducing sugar, alcoholic content) for each day (Ogodo 2015). 


\section{Determination of $\mathrm{pH}$}

This was determined by using the $\mathrm{pH}$ meter as described by Idise (2012).

\section{Determination of titratable acidity}

This was determined by the volumetric method, according to Analysis of Association of Analytical Chemist AOAC, (2005).

\section{Determination of reducing sugar}

This was done by the method of Miller (1959).

\section{Determination of specific gravity}

This was determined by the gravimetric method as recorded in AOAC (1980) using a relative density bottle

\section{Determination of alcohol content}

This was determined by the methods of the AOAC (1980).

\section{Determination of temperature}

This was done as described by Idise (2012).

\section{Sensory and organoleptic evaluation}

A nine-point scale hedonic test was conducted on the finished products by a panel of 25 trained and experienced wine tasters. The purpose was for both characterizations of the wine flavor profile and comparison with an existing brand. The test wine and control wine samples were anonymously presented to the panel along with a questionnaire to document their observations David et al (2013). They characterized the wine produced based on some attributes which were taste, aroma, color and texture.

\section{Statistical Analyses}

One-way Anova was employed to analyze the significant differences amongst the test samples at $95 \%$ confidence interval, using SPSS software version 22.

\section{Results}

\section{Viability test of yeast samples}

The result of the viability test of the yeast samples is as shown in Table 1. The viable counts of Saccharomyces cerevisiae, Saccharomyces bayanus and Saccharomyces ellipsoides after growth on YPG medium were $3.3 \times 10^{6}, 3.5 \times$ $10^{6}$ and $3.8 \times 10^{6} \mathrm{cfu} / \mathrm{ml}$ respectively.

Table 1 Viability tests of pure cultures of yeast samples.

\begin{tabular}{|c|c|}
\hline Yeast Samples & Viable Counts $\left(\times 10^{6} \mathrm{cfu} / \mathrm{ml}\right)$ \\
\hline Saccharomyces cerevisiae & 3.3 \\
\hline Saccharomyces bayanus & 3.5 \\
\hline Saccharomyces ellipsoides & 3.8 \\
\hline
\end{tabular}

\section{Determination of $\mathrm{pH}$}

There was a reduction in the $\mathrm{pH}$ of the different fermented pineapple wines. The $\mathrm{pH}$ of pineapple wine produced from Saccharomyces cerevisiae, Saccharomyces bayanus and Saccharomyces ellipsoides reduced from 5.20 to 5.00, 5.20 to 5.04 and 5.20 to 5.00 respectively across the 28 days of fermentation (Figure 1 ).

\section{Determination of titratable acidity}


The comparative analysis results of the titratable acidity of pineapple wine were shown in Figure 2. There was an increase in the titratable acidity of the pineapple wines. The titratable acidity of the pineapple wine from Saccharomyces cerevisiae, Saccharomyces bayanus and Saccharomyces ellipsoides increased from 0.41 to $1.10,0.45$ to 0.61 , and 0.45 to 1.18 respectively across the 28 days of fermentation.

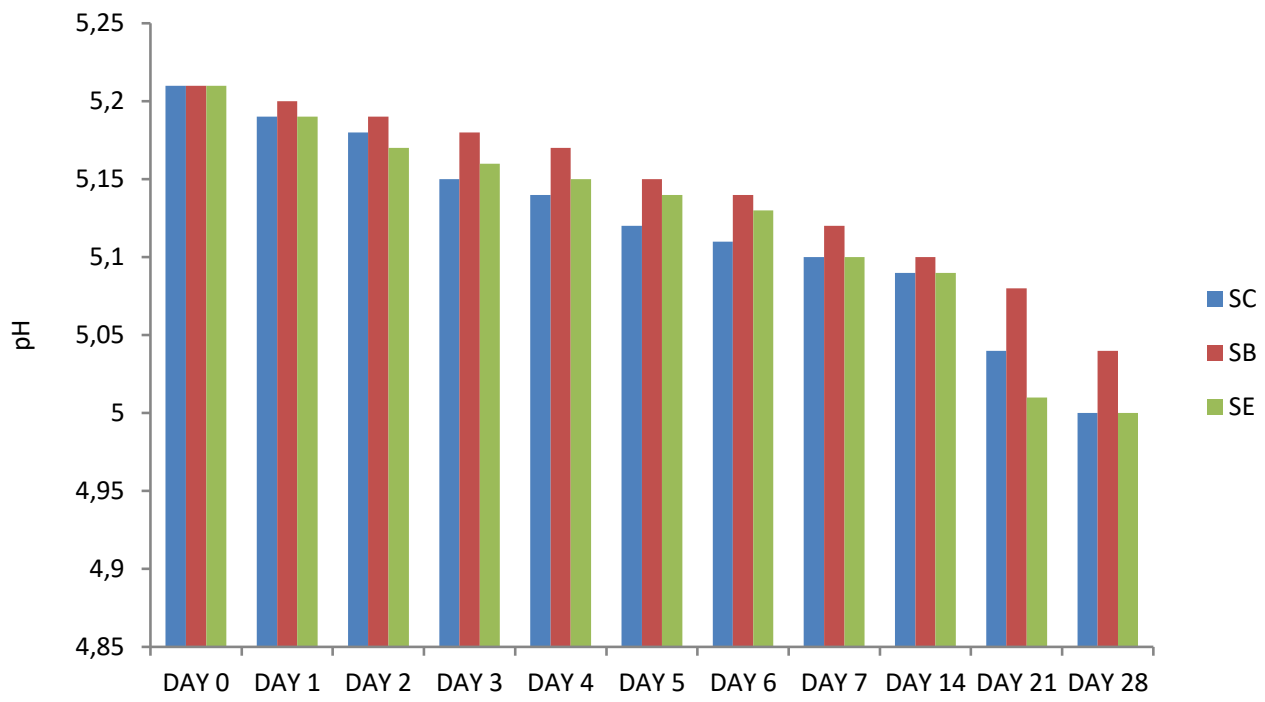

Figure 1 Comparative analyses of the pH of pineapple wine. SC: Saccharomyces cerevisiae. SB: Saccharomyces bayanus. SE: Saccharomyces ellipsoides.

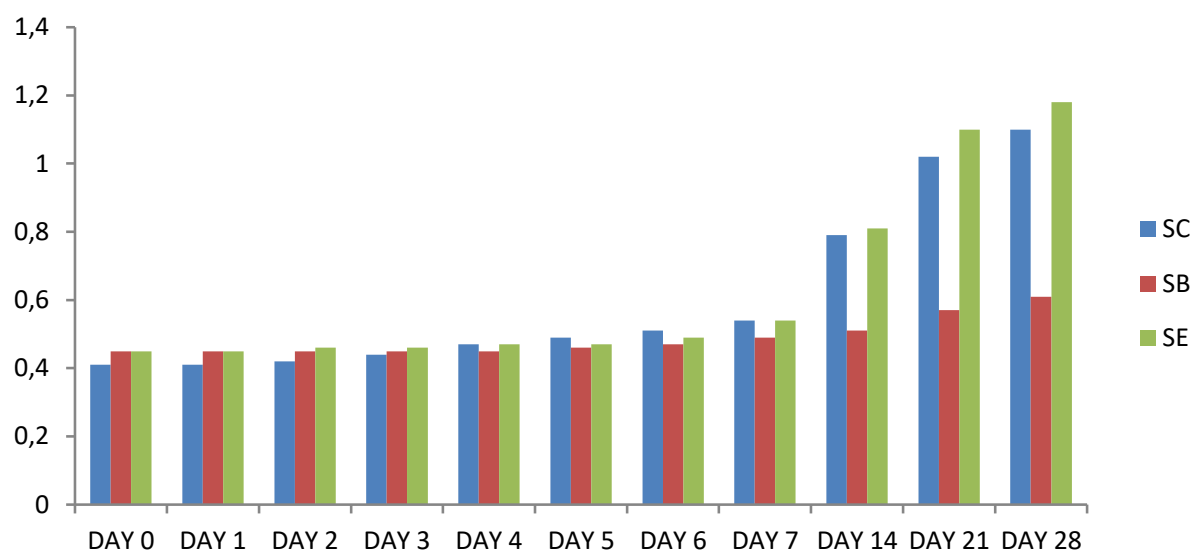

Figure 2 Comparative analyses of titratable acidity of pineapple wine. SC: Saccharomyces cerevisiae. SB: Saccharomyces bayanus. SE: Saccharomyces ellipsoides.

\section{Determination of reducing sugar}

There was a decrease in reducing sugar of the pineapple wines. The reducing sugar of the wine produced from Saccharomyces cerevisiae, Saccharomyces bayanus and Saccharomyces ellipsoides decreased from $4.50 \mathrm{mg} / \mathrm{ml}$ to 2.10 $\mathrm{mg} / \mathrm{ml}, 4.50 \mathrm{mg} / \mathrm{ml}$. to $2.10 \mathrm{mg} / \mathrm{ml}$ and $4.50 \mathrm{mg} / \mathrm{ml}$ to $2.30 \mathrm{mg} / \mathrm{ml}$ respectively across the 28 days of fermentation (Figure 3).

\section{Determination of specific gravity}

There was a reduction in the specific gravity of the pineapple wine. The specific gravity of the pineapple wine from Saccharomyces cerevisiae, Saccharomyces bayanus and Saccharomyces ellipsoides reduced from 1.005 to 0.9906 , 1.005 to 0.9904 , and 1.005 to 0.9907 respectively across the 28 days of fermentation (Figure 4).

\section{Determination of alcohol content}


The results of the comparative analyses of the alcohol content of pineapple wine were shown in Figure 5. The alcohol content of the pineapple wine produced from Saccharomyces cerevisiae, Saccharomyces bayanus and Saccharomyces ellipsoides increased from $0.13 \%$ to $6.60 \%, 0.20 \%$ to $6.75 \%$ and $0.26 \%$ to $6.53 \%$ respectively across the 28 days of fermentation.

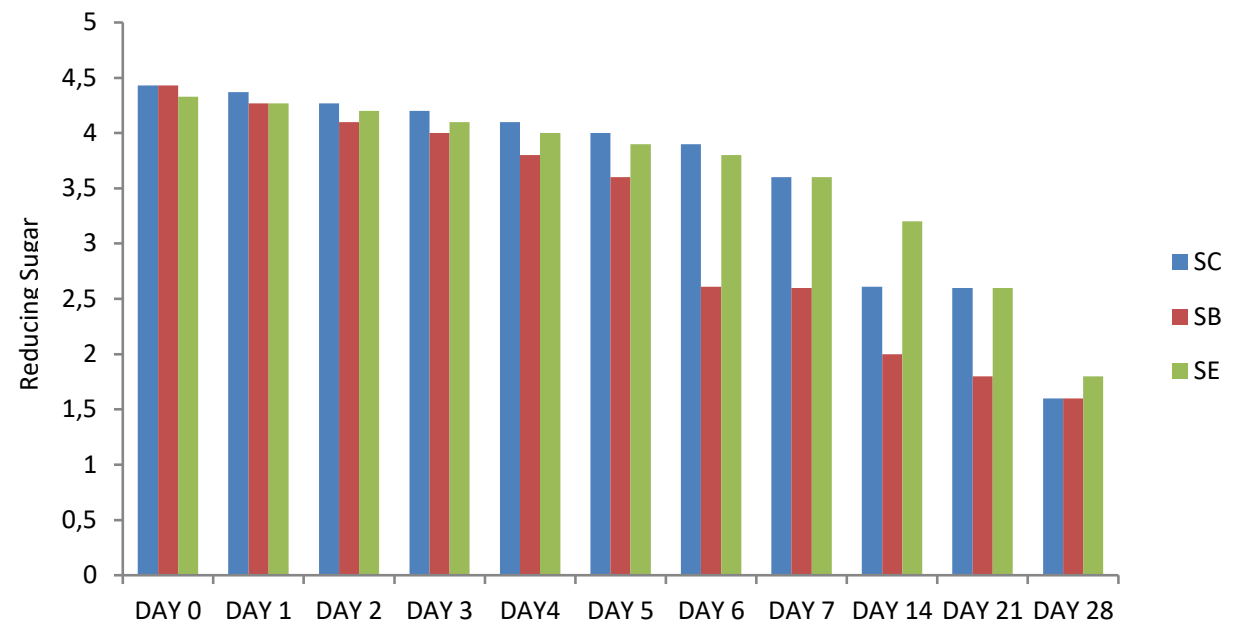

Figure 3 Comparative analyses of reducing sugar of pineapple wine. SC: Saccharomyces cerevisiae. SB: Saccharomyces bayanus. SE: Saccharomyces ellipsoides.

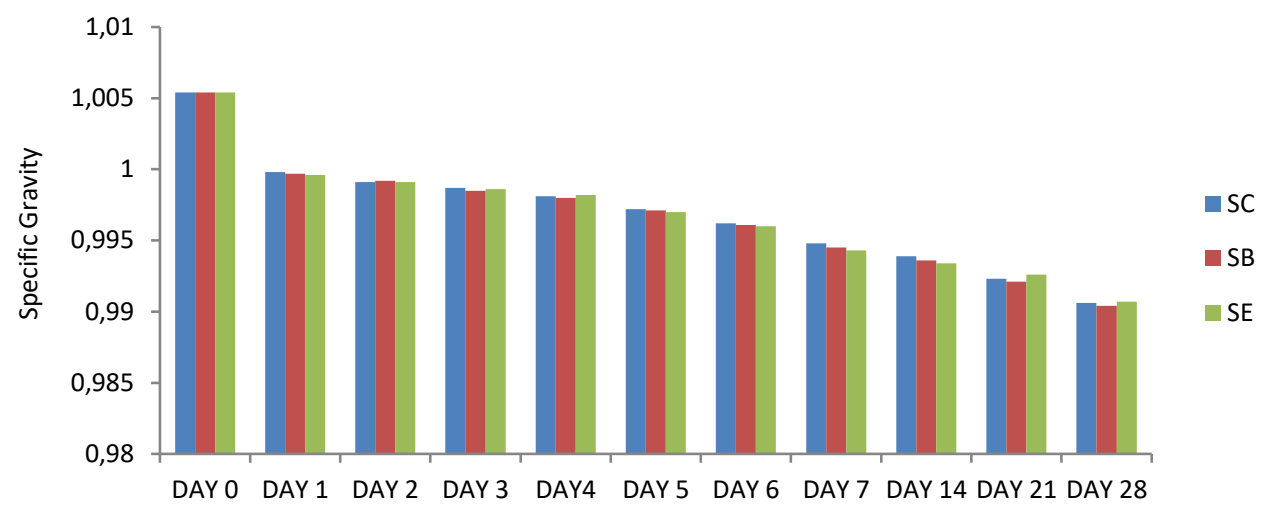

Figure 4 Comparative analyses of specific gravity of pineapple wine. SC: Saccharomyces cerevisiae. SB: Saccharomyces bayanus. SE: Saccharomyces ellipsoides.

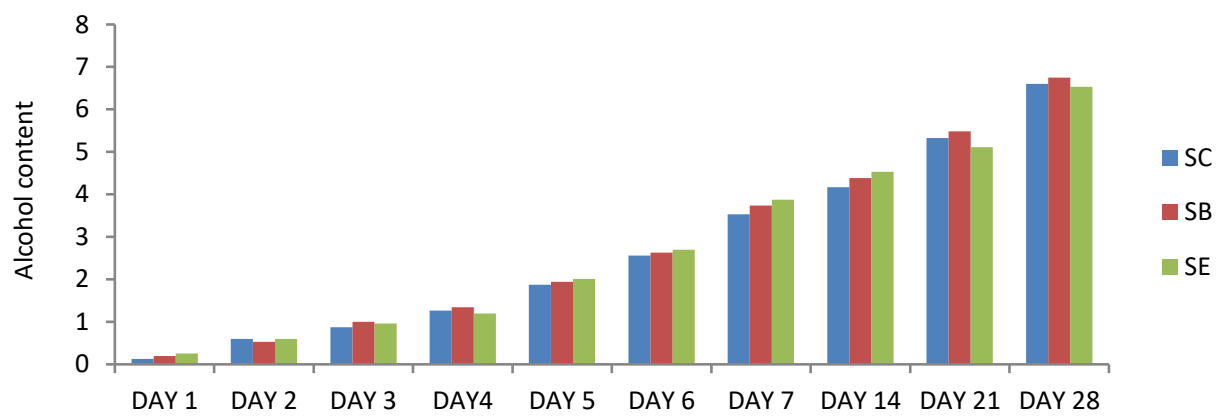

Figure 5 Comparative analyses of alcohol content of pineapple wine. SC: Saccharomyces cerevisiae. SB: Saccharomyces bayanus. SE: Saccharomyces ellipsoides.

\section{Determination of Temperature}

The results of the comparative analyses of the temperature of pineapple wine were given in Figure 6 . The temperature of pineapple wine produced from Saccharomyces cerevisiae, Saccharomyces bayanus, and Saccharomyces 
ellipsoides increased from $24.0^{\circ} \mathrm{C}$ to $24.2^{\circ} \mathrm{C}, 24.0^{\circ} \mathrm{C}$ to $24.2^{\circ} \mathrm{C}$, and $24.0^{\circ} \mathrm{C}$ to $24.1^{\circ} \mathrm{C}$ respectively across the 28 days of fermentation.

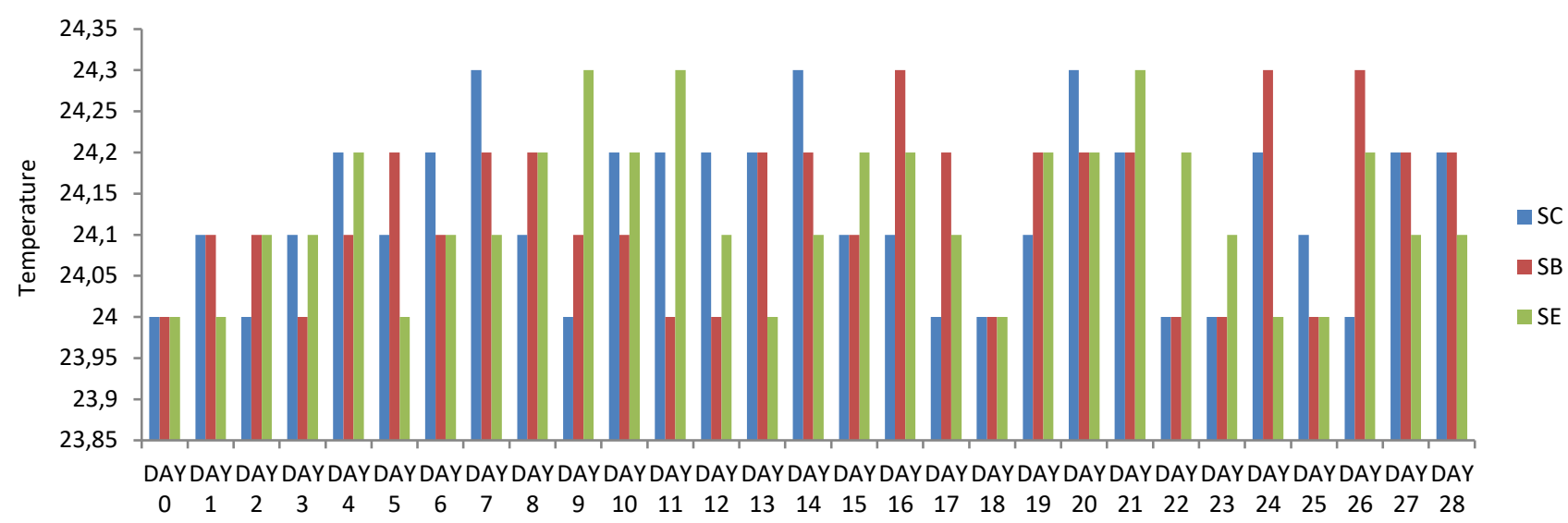

Figure 6 Comparative analyses of alcohol content of pineapple wine. SC: Saccharomyces cerevisiae. SB: Saccharomyces bayanus. SE: Saccharomyces ellipsoides.

\section{Sensory and Organoleptic Evaluation}

Taste panelists agreed on the wine taste from the test samples as all sweet. The aroma was graded as fruity smell, the color as golden yellow color and they all had smooth texture (table 2). Overall acceptability of the wine samples in comparison with standard table wine showed significant difference $(p<0.05)$ in Saccharomyces bayanus wine, while no significant differences existed amongst other test wine groups as shown in table 3.

Table 2 Sensory attributes of wine samples.

\begin{tabular}{lllll}
\hline Sensory Parameters & S. cerevisiae wine & S. bayanus wine & S. ellipsoides wine & Table wine \\
\hline Taste & Sweet & Sweet & Sweet & Sweet \\
Aroma & Fruity smell & Fruity smell & Fruity smell & Fruity smell \\
Colour & Golden-yellow & Golden-yellow & Golden-yellow & Pink \\
Texture & Smooth & Smooth & Smooth & Smooth \\
\hline
\end{tabular}

Table 3 Mean overall acceptability of the test wine samples.

\begin{tabular}{ll}
\hline Wine Samples & Mean \pm SD \\
\hline S. cerevisiae wine & $8.04 \pm 0.16$ \\
S. bayanus wine & $6.88 \pm 0.28^{*}$ \\
S. ellipsoides wine & $8.44 \pm 0.17$ \\
Table wine & $8.72 \pm 0.12$ \\
\hline ds for the significantly different acceptance level of wine sample
\end{tabular}

\section{Discussion}

The viable counts of Saccharomyces cerevisiae, Saccharomyces bayanus, and Saccharomyces ellipsoides as shown in Table 2, shows that the yeast samples were active and fit for use for the winemaking process. A comparative analysis of the changes in $\mathrm{pH}$ of the product wine showed a reduction in the $\mathrm{pH}$ within the period of fermentation from 5.20 to 5.00 this finding did not agree with the work of Idise (2012) who produced pineapple wine with Saccharomyces cerevisiae in which the $\mathrm{pH}$ was as low as 3.0-3.5. His reported low $\mathrm{pH}$ value could be as a result of the increased fermentation rate of the pineapple must because it was augmented with $6 \mathrm{~L}$ sugar solution; while our research method used just pure pineapple must with no sucrose augmentation hence, the $\mathrm{pH}$ range of 5.00-5.20. The reduction in $\mathrm{pH}$ could be attributed to the metabolic activities of the yeasts involved in the production of carbon-dioxide which is dissolved in the must to form carbonic acids thus, lowering the $\mathrm{pH}$. The increase in titratable acidity is due to the production of carbon-dioxide which is dissolved in the must forming carbonic acids which add to the acids naturally found in the fruits. An excessive increase in the titratable acidity could lead to the production of wines with a vinegarlike taste and the eventual death of the yeast isolates. Titratable acidity reported by Idise (2012) falls in the same range as that obtained from our fermentation using the three yeast samples. The general reduction in reducing sugar and a 
specific gravity of the wine is due to constant utilization of the sugar in the must by the yeasts isolates and subsequent conversion to alcohol.

A comparative analysis of the alcohol content of the product wines showed a steady increase in all the produced wines. This could be as a result of the production of ethanol through the conversion of sugars in the must due to the yeast's metabolism. Idise (2012) and Qi et al (2017) reported an increased percentage of alcohol concentrations from their pineapple wine production experiments. However, Qi et al (2017) reported $10.2 \%$ alcohol which was higher than our alcoholic content of 6.53-6.75\%. Likewise, Idise (2012) reported a different alcohol concentration of $1.35 \%$ which is notably lower than the alcohol concentration of our wine. These noted differences in alcohol concentrations could be attributed to yeast strains and also to the duration of fermentation. Idise (2012) fermented for 6 days, Qi et al (2017) fermented for 7 days while our fermentation lasted for 28 days. There was no significant difference $(p>0.05)$ in the alcohol content amongst our different product wine. There was no significant $(p>0.05)$ difference in the temperature amongst the compared wine samples. The temperature ranges of $24.0^{\circ} \mathrm{C}$ to $24.2^{\circ} \mathrm{C}$, have been posited by Thias et al (2006), to support good growth of yeast samples during winemaking. This is because the excessive increase in temperature of the wine could lead to the sudden death of the yeast isolates thereby halting the fermentation process. The taste panelist's recommendations show a notable level of acceptance to the sensory attributes of the test wine samples ranging from their flavor to appearance, and their overall level of likeness and acceptability is suggestive of the fact that pineapple serves as a good locally sourced raw material for indigenous wine production. Idise (2012) reported good acceptability of pineapple wine based on its flavor and aroma, Archibong et al (2015) and Dellacassa et al (2016) reported its acceptance based on flavor while Qi et al (2017) reported pineapple wine acceptance based on it being a low alcoholic wine.

\section{Conclusion}

There is a great need for the development of industries that will make use of local and cheap raw materials like pineapple to produce wine to take care of the increasing demand of wine consumption and cut off post-harvest preservation losses of fruits in the country. Pineapple makes a good compatible raw material for wine production using varying yeast samples.

\section{Conflict of Interest}

The authors declare no conflict of interests

\section{References}

AOAC (1980) Percentage by volume of alcohol corresponding to apparent specific gravity at various temperatures. National Beareau of Standards 9:889-891.

AOAC (2005) Official methods of Analysis of Association of Analytical Chemist (AOAC). Washington DC.

Archibong EJ, Ezemba CC, Chukwujama IC, Archibong EU (2015) Production of wine from mixed fruits: pineapple (Ananas comosus) and Orange (Citrus sinensis) using yeast isolated from palm wine. World Journal of Pharmacy and Pharmaceutical Sciences 4:126136.

Chaudhary V, Kumar V, Vaishali S, Singh K, Kumar R, Kumar V (2019) Pineapple (Ananas comosus) product processing: A review. Journal of pharmacognosy and Phytochemistry 8:4642-4652.

David G, Ella P, Monica L (2013) Sensory descriptors, hedonic perception and consumer attitude to sangiovese red wine. Journal of Sensory Studies 10:3-6.

Dellacassa E, Trenchs O, Farina L, Debernardis F, Perez G, Boido E, Carrau F (2016) Pineapple (Ananas comosus L. Marr) wine production in Angola: Characterization of volatile aroma compounds and yeast native flora. International Journal of Food Microbiology 241:161-167.

Jana AH (2011) Ultra High-Temperature (UHT) processing and pasteurization effects on shelf-life of product. Journal of Food Science $10: 251-268$

Idise OE (2012) Studies of wine produced from pine apple (Ananas comosus). International Journal of Biotechnology and Molecular Biology Research 3:1-7. 
Miller GC (1959) The use of DinitroSalicylic acid reagent for Determination of Reducing Sugars. Journal of Analytical Chemistry 31:427431.

Mirek M, Tecza R (2014) Comparison of method used for assessing the viability of yeast Cells. Journal of Yeast Research 14:10681069.

Ogodo AE (2015) Production of mixed fruit wines using Saccharomyces. Cerevisiae isolated from palm wine. Journal of Food Science 4:183-184.

Qi N, Ma L, Li L, Gong X, Ye J (2017) Production and quality evaluation of pineapple fruit wine. IOP conference series: Earth and Environmental Science 100:012028. Doi:10.1088/1755-1315/100/1/012028.

Thias MG, Tania MB, Cynthia MT (2006) Isolation and characterization of Saccharomyces cerevisiae strains of winery interest. Brazilian Journal of Pharmaceutical Scienc, 2:50-54. 